\title{
Evaluating Potential and Feasibility of Wind Energy Considering Restriction of Plant Location
}

\author{
Keiichi OKAJIMA ${ }^{\dagger}$ and Masato OISHI \\ (Received November 15, 2016)
}

\author{
立地制約を考慮した風力発電の導入および事業性に関する評価 \\ 岡島敬一"，大石嗁人
}

\begin{abstract}
Renewable energy has been developed in Japan to actualize the sustainable society. It is also expected to contribute rehabilitation razed by Great East Japan Earthquake. Iwate prefecture has great wind resources potential among disaster-stricken areas. We have evaluated the wind energy by wind turbines in Iwate prefecture with Geographic Information System (GIS) taking into account restriction for the plant location and business feasibility. Furthermore, we have analyzed sensitivity analysis of feasibility and assessed the case of bigger or less expensive wind turbines. As the results, wind power in Iwate prefecture has capable of generating $73.4 \mathrm{TWh}$ for one year with the levelized cost of $24.7 \mathrm{Yen} / \mathrm{kWh}$. For the location which has above $8 \%$ of the internal rate of return (IRR), the total amount of annual electricity and the levelized cost are estimated to $3.0 \mathrm{TWh}$ and $15.4 \mathrm{Yen} / \mathrm{kWh}$, respectively. The available area is $232 \mathrm{~km}^{2}$ and this accounts for only $1.5 \%$ of the whole. The improvement of IRR is expected by the installation of larger wind turbines, though the available area increases only slightly with the cost reduction case.
\end{abstract}

再生可能エネルギーは持続可能な社会構築のため導入が進められてきているが, 東日本大震災後, 環境課題への対策 のみならず，災害やエネルギーリスクに強い地域づくりの面からも，太陽光発電や風力発電といった再生可能エネルギーヘ の関心が高まっている。特に岩手県は震災の被害を受けた中でも風況が良い地域である。本論文では, 風力発電の開発 の際に関係する様々な条件を地域ごとに整理し，地理情報システム (GIS) を用いて，開発可能地域の検討を行った。また， それらの地域へ風力発電機を導入した際の正味年間発電量を算出することで, 岩手県における風力発電の導入評価を行っ た。加えて, 将来的にコストが低減された場合㧍よび風車の大型化が可能となった場合の事業性についても評価を行った。

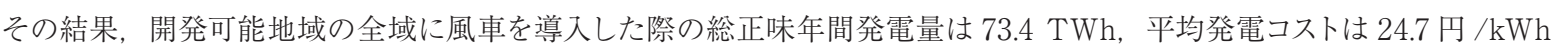
となり, 事業性の基準值を内部収益率 (IRR) $8 \%$ 以上と設定すると, これを満たす総面積は $232 \mathrm{~km}^{2}$ と岩手県全域に対

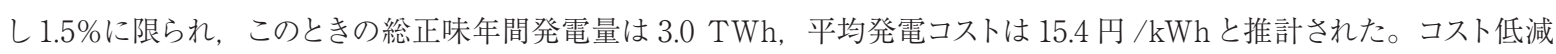
を考慮したケースでは導入可能面積は微増に留まるが, 大型風車導入を想定したケースに扔いては, IRRが全体的に増加し, 風車の大型化によって事業性の向上が期待される。

\section{Key Words}

Wind energy, Potential evaluation, Feasibility, IRR, GIS

\section{1. はじめに}

東日本大震災後, 環境課題への対策のみならず, 災害や エネルギーリスクに強い地域づくりの面からも, 太陽光発電 や風力発電といった再生可能エネルギーへの関心が高まって いる。再生可能エネルギーは, 化石燃料に代わる持続可能

\section{University of Tsukuba}

SB, 1-1-1, Tennodai, Tsukuba-shi, Ibaraki 305-8573, Japan

† Corresponding author: okajima@risk.tsukuba.ac.jp
なエネルギーとして注目されると同時に, 自律分散型のエネ ルギー供給システムを構築することができるため, 地域エネ ルギー供給を目指したメガソーラー, ウインドファームの導入 や, より小さい規模では, 避難所等への導入が期待されて いる ${ }^{1}$ 。

筑波大学大学院システム情報工学研究科

于 305-8573 茨城県つ〈ば市天王台 1-1-1 総合研究棟 B 
再生可能エネルギーのひとつである風力発電では, 開発 が可能な地域を定義することが難しいという課題がある。こ れは技術面や環境面, 社会面といった様々な要素が関係し, 複雑化しているためである。複数の要素を整理するためには, 地理情報システム (Geographic Information System, GIS) が 用いられることが多い。例えば都市における一般廃棄物管理 に関する評価 ${ }^{2)}$, 再生可能エネルギーのポテンシャル評価 ${ }^{3)}$, バイオマス資源ポテンシャルならびに分布評価 ${ }^{4)}$, などの研 究が報告されている。風力発電に関しても, GIS を用いて開 発可能地域を選定し年間発電量等を推計したものがあり, スウェーデンを対象に, 開発可能地域シナリオを設定して抽 出し年間発電量を推計している5)。

一方, 風力発電は発電コストが火力発電に対し比較的高 いため導入が進まないという課題も存在する。既往報告には 売電価格等を考慮することで, 各地域における風力発電の 事業性を評価した研究も存在する 6) 7)。これらの研究により 開発可能地域の検討に考慮すべき条件や, 風況情報に確率 分布を用いることで, より詳細な年間発電量を推計可能なこ とが示されてきている。しかし, 技術特性や, 環境条件, 社 会条件等を配慮しているが, 経済性を含めた風力発電のポ テンシャル評価ができていない。特に導入適地の検討には, 地形的条件や環境的条件, 社会的条件, 技術的条件など, 様々な要素を考慮する必要があり, 非常に複雑である。

本論文では, 様々な条件を整理し風力発電の導入及び事 業性の評価を行うことを目的とした。GIS を用いて風力発電 開発可能地域を選定し, 事業性評価ならびに事業性に関す る感度分析を行い, 導入ポテンシャルがどのように推移する のか検討した。また, 将来的に風車が大型化した際や, 風 力発電の導入コストが低減した際の, 事業性の推移について も評価を行った。対象地域は, 東日本大震災の被災地域の 中でも, 再生可能エネルギーのポテンシャルが高い岩手県と した。

岩手県では, 2012 年 3 月に岩手県地球温暖化対策実行計 画が策定され，2016 年3月に改訂された ${ }^{8)}$ これは, 2011 年に発生した東日本大震災の復興計画に示された, 再生可 能エネルギーの導入促進に向けた具体的な取り組み計画も 含む。この計画の中では, 2020 年までの再生可能エネルギー の導入想定量 (Table 1) が設定されており, この目標の達 成により, 二酸化炭素の排出量が $569 \mathrm{kt}-\mathrm{CO}_{2}$ 削減可能だと

Table 1 Renewable Energy Target in Iwate Prefecture ${ }^{8)}$

\begin{tabular}{l|c|c|c}
\hline & 2010 & \multicolumn{2}{|c}{2020} \\
\hline & $\begin{array}{c}\text { Capacity } \\
{[\mathrm{kW}]}\end{array}$ & $\begin{array}{c}\text { Capacity } \\
{[\mathrm{kW}]}\end{array}$ & $\begin{array}{c}\text { Increase rate } \\
{[\%]}\end{array}$ \\
\hline Solar photovoltalic & 34,740 & 747,663 & 2,052 \\
\hline Wind power & 67,099 & 475,699 & 609 \\
\hline Hydro power & 274,576 & 276,001 & 1 \\
\hline Geothermal & 103,500 & 110,999 & 7 \\
\hline Biomass & 1,724 & 40,954 & 2,275 \\
\hline Total & 481,639 & $1,651,316$ & 97 \\
\hline
\end{tabular}

見積もられた。風力発電に注目すると, 2010 年からの増減 率が $609 \%$ と非常に高く, 再生可能エネルギーの中でも成長 が期待されている。

\section{2. 分析手法および前提条件}

本論文における分析手法の概要を Fig. 1 に示す。風力発 電の導入ポテンシャルを推計するためには, 第一に, 風力発 電設備の開発が可能な地域を抽出する必要がある。そこで 本論文では岩手県を $500 \mathrm{~m}$ 四方のメッシュへ細分化し, 各 条件に基づき, GIS を用いて風力発電の開発可能地域を求 めた。また, 風況デー夕と風車の出力カーブのデータを用い て, 各メッシュにおける年間発電量を推計した。その後, 初 期投資費用や保守管理費用, 収益等を入力データとして内 部収益率 (Internal rate of return, IRR) を算出した。それら の結果を用いて, 岩手県に扔ける風力発電の導入ポテンシャ ルと事業性の評価を行なった。GIS ソフトウェアとして, Arc GIS 10.2 を用いた。

\section{1 検討ケース}

風力発電の効率化抢よびコストの削減を目的として, 風力 発電システム (風車) の大型化が進んでいる。近年の日本 では $2 \mathrm{MW}$ 級の風車の導入実績が多い。そこで本論文にお いても, 定格出力 $2 \mathrm{MW}$ の風車を導入することを想定した。 これを基準ケースとし, 世界風力会議 (Global Wind Energy Council, GWEC) によるコスト低減シナリオに基づいた「コス 卜低減ケース」と, 将来的に風車のさらなる大型化が進むこ とが予想され,「大型風車導入ケース」についても検討を行っ た。

·基準ケース (定格出力 $2 \mathrm{MW}$ 風力発電機導入)

・コスト低減ケース（4\%低減および 12\%低減シナリオ)

·大型風車導入ケース $(5 \mathrm{MW}$ 風力発電機導入, コストは 基準ケースと同等)

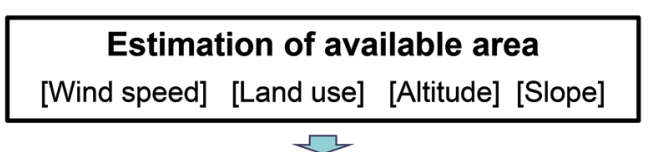

Total annual electricity generation

[Wind condition], [Power curve],

[Utilization factor], [Correction factor]

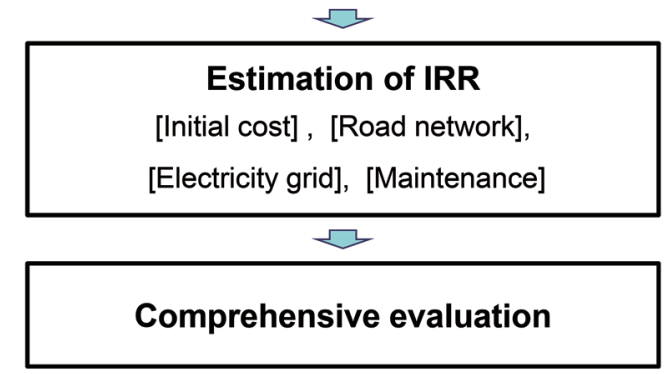

Fig. 1 Potential and feasibility evaluation of wind energy 


\section{2 開発可能地域の抽出}

風力発電の導入ポテンシャルを推計する際には, 風況だ けでなく建設地点傾斜などの自然条件や，土地利用などの 社会的条件を考慮する必要がある。このような複数の制約 条件を重ね合わせ，各地点について面的に評価を展開する にはGISでの分析は有力な手法である。そこで本論文では GIS を用いて, 制約条件を考慮し風力発電の開発可能地域 を抽出した。

GIS データとして，国土交通省国土政策局の国土数值情報 ダウンロードサービスにおいて様々な情報が一般公開されて いる。これは，国土形成計画，国土利用計画等の策定や国 土政策の推進に資するため，基礎的な情報を整備したもの である。公開デー夕は, 海岸線や河川等の水域情報, 森林 地域や農業地域等の土地利用情報, 気候值等の自然情報, 自然公園や自然保全等の指定地域情報，公共施設や発電 所等の施設情報，工業や商業統計等の産業情報など，多種 多様な情報がメッシュ，ポリゴン，ライン，ポイント情報とし て整備されている。本論文では国土数值情報ダウンロード サービスより，行政区域，土地利用種別細分メッシュ，自然 公園地域, 自然保全地域, 鳥獣保護区, 森林地域, 空港 のデータを用いた9)。

また，国土交通省国土地理院の数值地図（国土基本情報） においても様々な情報が販売されている。これは，国土地 理院が整備してきた基盤地図情報，数值地図シリーズ，数 值標高データを統合し，さらに各種デー夕項目を追加した総 合的な地理空間情報である。公開デー夕は，行政区画情報 や道路情報，建物情報，地形情報，公共施設情報，構造 物情報などである。本論文では数值地図（国土基本情報） より，標高，道路，送電線のデー夕を用いた ${ }^{10)}$

日本における風力発電の開発時に考慮すべき条件は議論 が進められており，報告書としてまとめられている。特に環 境省報告書では社会条件として土地利用条件のみならず法 規制条件として航空法による制限も考慮した精緻な検討が 行われてきている11) 14)。本論文では NEDO 風力発電導入 ガイドブック ${ }^{15)}$ ， および前述の環境省報告書 ${ }^{11)} \sim 14$ ), 地方自 治体として岩手県の風力発電導入構想策定報告書 16$)$ を参考 に検討し，制約条件を Table 2 に示す標高，傾斜，土地利 用種別㧍よび年平均風速に絞りこみ, 開発可能地域を抽出 した。これらに該当しない地域を岩手県の行政区域内から 除外することで, 開発可能地域を抽出した。

Table 2 Consideration for evaluation of available area ${ }^{11) ~ ~ 16) ~}$

\begin{tabular}{l|c|c}
\hline & Condition & Data mesh \\
\hline Wind speed & $>5 \mathrm{~m} / \mathrm{s}$ & $500 \mathrm{~m}$ \\
\hline Land use & Forest, Agriculture, Waste land & $100 \mathrm{~m}$ \\
\hline Altitide & $<1,000 \mathrm{~m}$ & $50 \mathrm{~m}$ \\
\hline Slope & $<20^{\circ}$ & $50 \mathrm{~m}$ \\
\hline
\end{tabular}

\section{3 対象風力発電システムおよび正味年間発電量の算出}

本論文で対象とした定格出力 $2 \mathrm{MW}$ の風力発電機および 「大型風車導入ケース」において対象とした定格出力 $5 \mathrm{MW}$ 風力発電機の諸元を Table 3 に示す 17) 19)。 $2 \mathrm{MW}$ 機はロー 夕直径が $80 \mathrm{~m}$ ，ハブ高さが $78 \mathrm{~m}$ であり，カットイン風速は $4 \mathrm{~m} / \mathrm{s}$, カットアウト風速は $25 \mathrm{~m} / \mathrm{s}$, 定格風速 $13 \mathrm{~m} / \mathrm{s}$ で出 カ $2 \mathrm{MW}$ を達成する。 $5 \mathrm{MW}$ 機は, カットイン風速, カット アウト風速は $2 \mathrm{MW}$ と変わらず，風速 $13 \mathrm{~m} / \mathrm{s}$ で出力 $5 \mathrm{MW}$ を達成し，ロー夕直径打よび八ブ高さはそれぞれ $126 \mathrm{~m}$ なら びに $90 \mathrm{~m}$ である。

年間発電量 $\left(E_{a p}\right)$ は, 風車の発電出力と各風速の出現確 率（ワイブル分布）を用い, 式（1）によって算出した。

$$
E_{a p}=\Sigma(P(V) \times f(V) \times T)
$$

ここで, 風速 $V$ における発電出力 $P(V)$ は式 $(2)$ を, 風速 $V$ の出現確率 $f(V)$ は式 $(3)$ を用いて算出した。また $T$ は 1 年間 の総時間数で 8760 時間である。

$$
\begin{aligned}
& P(V)=\frac{1}{2} \rho A V^{3} C_{p} \\
& f(V)=\frac{k}{c}\left(\frac{V}{c}\right)^{k-1} \exp \left\{-\left(\frac{V}{c}\right)^{k}\right\}
\end{aligned}
$$

各式における変数は以下のとおりである。 $\rho$ は空気密度で, 日 本の平地 (1 気圧, 気温 $15^{\circ} \mathrm{C}$ ) での平均值 $1.225 \mathrm{~kg} / \mathrm{m}^{3}$ とし た ${ }^{15)}$ 。 $A$ は風車の受風面積で, $2 \mathrm{MW}$ 機で $4,978 \mathrm{~m}^{2}, 5 \mathrm{MW}$ 機では $12,469 \mathrm{~m}^{2}$ である。 $C_{P}$ は風速 $V$ における風車の出力 係数で, $2 \mathrm{MW}$ 機についてはカタログ值 ${ }^{18)}$ を用い, $5 \mathrm{MW}$ 機についてはパワーカーブ 19) より概算した。 $k$ および $c$ はそれ ぞれ，ワイブル分布の形状係数と尺度係数で，NEDOの局 所風況マップ 20)に基づき, 各 $500 \mathrm{~m}$ メッシュ全てに適用した。 なお， $2 \mathrm{MW}$ 機および $5 \mathrm{MW}$ 機のどちらにおいても，地上 高 $70 \mathrm{~m}$ の值を用いている。前述の通りハブ高さは $2 \mathrm{MW}$ 機で $78 \mathrm{~m}, 5 \mathrm{MW}$ 機では $90 \mathrm{~m}$ と, 地上高 $70 \mathrm{~m}$ よりも高く, 特に $5 \mathrm{MW}$ 機の場合は上空となるため風速が高くなり発電 電力量が増大するが，本論文では，簡素化のために，風速 の高度補正を考慮していない。

実際の風力発電には, 故障修理など発電量を低減させる 要因が存在する。また，風車の風下側には，風の乱流が発 生するウェーク領域が存在するため, 複数の風車を設置する 際には，風車間に一定距離を置く必要がある。これらを考 慮するため, 式 (4)を用いて各 $500 \mathrm{~m}$ メッシュに対し正味年 間発電量 $\left(E_{n a p}\right)$ を算出した。

Table 3 Wind turbine specifications ${ }^{17) \sim 19}$

\begin{tabular}{l|c|c}
\hline Rated power output & $2 \mathrm{MW}$ & $5 \mathrm{MW}$ \\
\hline Cut in speed & $4 \mathrm{~m} / \mathrm{s}$ & $4 \mathrm{~m} / \mathrm{s}$ \\
\hline Cut out speed & $25 \mathrm{~m} / \mathrm{s}$ & $25 \mathrm{~m} / \mathrm{s}$ \\
\hline Rated speed & $13 \mathrm{~m} / \mathrm{s}$ & $13 \mathrm{~m} / \mathrm{s}$ \\
\hline Roter diameter & $80 \mathrm{~m}$ & $126 \mathrm{~m}$ \\
\hline Swept area & $4,978 \mathrm{~m}^{2}$ & $12,469 \mathrm{~m}^{2}$ \\
\hline Hub height & $78 \mathrm{~m}$ & $90 \mathrm{~m}$ \\
\hline Altitude & $1,000 \mathrm{~m}$ or less & $1,000 \mathrm{~m}$ or less \\
\hline
\end{tabular}


$E_{\text {nap }}=\alpha \times C_{a v} \times C_{p f} \times E_{a p}$

ここで, $\alpha$ は $500 \mathrm{~m}$ メッシュあたりに導入可能な風車の基数 を示す面積係数である。本論文では Fig. 2 に示す通り, 風 車のロー夕直径 $D$ の 10 倍を風車間の最低必要距離 $(10 D \times$ $10 D ）$ とし，風車を設置することを想定した ${ }^{15)}$ 。2 MW 機お よび $5 \mathrm{MW}$ 機における風車のロー夕直径 $D$ は $80 \mathrm{~m}, 126 \mathrm{~m}$ であるため, 風車 1 基に必要な面積はそれぞれ $0.554 \mathrm{~km}^{2}$, $1.37 \mathrm{~km}^{2}$ となり，よって $2 \mathrm{MW}$ 機および $5 \mathrm{MW}$ 機における 面積係数 $\alpha$ はそれぞれ 0.451 および 0.182 と算出された。な お，実際の風力発電導入に際しては風車の基数は整数でな ければならず，実数值である面積係数 $\alpha$ を用いて算出した本 論文での正味発電量は，その観点において実際の発電量よ りも過大に評価している可能性が残ることに留意頂きたい。

この面積係数 $\alpha$ を $1 \mathrm{~km}^{2}$ あたりの導入設備容量に換算す ると, $2 \mathrm{MW}$ 機および $5 \mathrm{MW}$ 機ではそれぞれ $3.61 \mathrm{MW} / \mathrm{km}^{2}$ および $3.65 \mathrm{MW} / \mathrm{km}^{2}$ であり, これら導入設備容量の值は, 環境省報告書 $\left.{ }^{11)} 12\right)$ に扔ける $10 \mathrm{MW} / \mathrm{km}^{2}$ と比較して $1 / 3$ 程 度に相当する。環境省の值は卓越風向が顕著である場合を 前提としており, 風車の風下に形成される風況の乱れた領 域であるウェーク領域を, 風向と直角方向に風車のロー夕直 径 $D$ の 3 倍の $3 D$, 風下方向に 10 倍の $10 D$, とした $「 10 D$ $\times 3 D 」$ に基づいた数值を使用している ${ }^{12)}$ 。一方，本論文で は顕著な卓越風向が出現しない場合の推奨である $「 10 D \times$ $10 D 」$ (Fig. 2) を用いて算出しており，より保守的な想定に 基づいているといえる。なお， $2 \mathrm{MW}$ 機および $5 \mathrm{MW}$ 機の 比較では，風車間の最低必要距離を考慮すると結果的に面

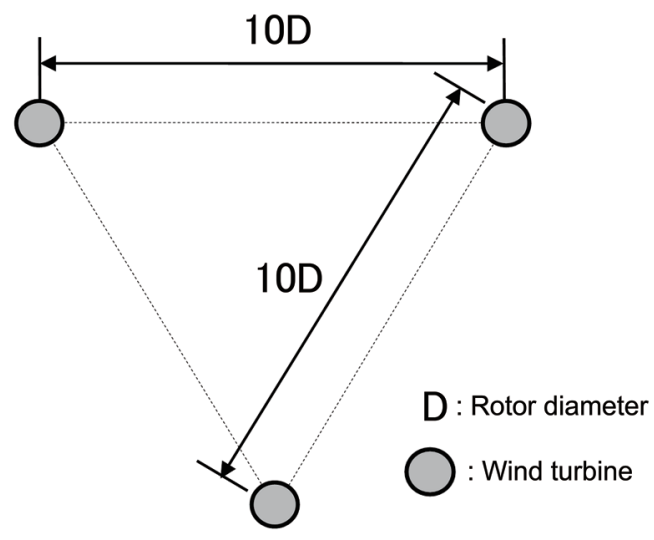

Fig. 2 Turbine spacing in a wind farm ${ }^{15}$
積あたりの設備容量に大きな差は生じない。

$C_{a v}$ は故障修理や定期点検によって風車が停止し, 年間発 電量が低減することを考慮したアベイラビリティで, 0.95 と した ${ }^{15)}$ 。また, $C_{p f}$ は風向変動や突風等によって出力が低下 することを考慮した出力補正係数で，0.90 とした ${ }^{15)}$ 。

\section{4 事業性の評価}

風力発電の開発に必要な費用は, 風車本体のみならず, 機材搬入のための道路の建設や送電系統の整備に必要な費 用も含まれる。地域によって既存の道路や送電線へのアクセ ス性は異なるため, 結果として, これらの整備に必要な費用 も異なる。これらの初期投資費用が多く必要となる地域で は, 風況が良い場合でも, 経済的な困難性から風力発電の 導入は進まない。本論文では, $500 \mathrm{~m}$ メッシュごとに風力 発電の導入に必要な費用を算出し, また, 発電量と想定し た売電単価を乗じることで得られる収益を用いて, 風力発 電の事業性を評価した。想定売電単価は固定価格買取制度 （FIT）の調達価格に基づき 22 円 $/ \mathrm{kWh}$ と設定した ${ }^{21)}$ 。

事業性の評価には式 (5)によって求まる内部収益率 (IRR) を用いた。

$$
\sum_{y=1}^{y r} \frac{C F_{y}}{(1+r)^{y}}-C I=0
$$

$y r$ は投資回収年数で, 20 年とした。CF キャッシュフローで，年間発電量と想定売電単価の積である 収益と保守点検費用を考慮した。CI は初期投資費用で, 設 備費用および道路整備費用，送電線敷設費用，開業費用を 考慮した。道路整備費用は幅員 $5.5 \mathrm{~m}$ 以上の道路から風力 発電設備の開発箇所までの直線距離を算出し, 迂回経路を 考慮するため, その 2 倍の距離が必要とした。また, 道路 整備費用と送電線敷設費用は土地利用種別情報を用いて, 平地と山岳地ごとに必要な単価を変化させた。それぞれの 費用単価を Table 4 に示す ${ }^{11}$ 。 $。$ 以上の值によって決定される 割引率 $r$ が IRR である。IRR は投資によって得ることのでき る利回りを比較する投資判断指標である。この值が大きいほ ど収益率が大きいことを示す。

風力発電の開発に必要なコストは将来的に低減すること が予想される。本論文では, 岩手県の再生可能エネルギー 導入目標量の達成年である 2030 年に扔ける風力発電のコス 卜を推計した。世界風力会議（GWEC）では, 2030 年まで に風車の本体および運転保守に必要なコストが, Moderate

Table 4 Cost assumptions for feasibility evaluation ${ }^{11)}$

\begin{tabular}{l|l|l|l}
\hline \multirow{4}{*}{ Initial cost } & \multicolumn{2}{|l|}{ Specific cost } & 0.25 Million Yen $/ \mathrm{kW}$ \\
\cline { 2 - 4 } & \multirow{2}{*}{ Road construction } & plain field & 25 Million Yen $/ \mathrm{km}$ \\
\cline { 2 - 4 } & mountainous & 85 Million Yen $/ \mathrm{km}$ \\
\cline { 2 - 4 } & $\begin{array}{l}\text { Electricity grid } \\
\text { construction }\end{array}$ & plain field & 35 Million Yen $/ \mathrm{km}$ \\
\cline { 2 - 4 } & mountainous & 55 Million Yen $/ \mathrm{km}$ \\
\hline \multirow{2}{*}{ Cash flow } & Oapital cost & $600 \mathrm{Million}$ Yen per unit \\
\cline { 2 - 4 } & Electricity selling price & $6,000 \mathrm{Yen} / \mathrm{kW}$ \\
\hline
\end{tabular}


Scenario（MS）において4\%, Advanced Scenario（AS）に おいては $12 \%$ 低減されると予測している ${ }^{22}$ 。そこでこれらの シナリオに基づき，コストが低減された際のIRRを算出し, 事業性についての評価も行なった。

\section{3. 風力発電の導入評価}

岩手県全域を $500 \mathrm{~m}$ 四方のメッシュへ細分化し, 各メッシュ に導入できる風力発電設備の定格容量を求め, それを導入 した際の正味年間発電量を算出した。そして, 開発可能地 域のマップとオーバーレイすることで, 開発可能地域のみに 打ける正味年間発電量を抽出し, 風力発電の導入性を評価 した。

\section{1 年間発電量推計}

設定した条件に基づき風力発電の開発可能地域を抽出し, その地域に対して風力発電を導入した際の発電量を推計し た。平均風速制約, 土地利用制約, 標高制約, 傾斜制約を 考慮し開発可能地域を抽出した。これを Fig. 3 に示す。

この抽出された開発可能地域分布に基づき， $500 \mathrm{~m}$ メッ シュごとに推計した正味年間発電量の分布を Fig. 4 に示す。 本論文で設定した条件では，岩手県全域に遍在的に開発 可能地域が存在しており, この面積は, 岩手県の面積の約 $53 \%$ に相当する $8,133 \mathrm{~km}^{2}$ であった。また, 開発可能地域 の全てに風力発電を導入すると, 年間で $73.4 \mathrm{TWh}$ の発電 量を見込むことが可能である。これは，岩手県の電力需要 （2014 年）の 8.5 倍に相当する ${ }^{23)}$ 。

\subsection{IRR による事業性評価}

風力発電の開発の事業性を評価するために, IRRを推計 した。風力発電では，開発が進むためにIRR が $8 \%$ 上回 る必要があるとされている ${ }^{11}$ 。そこで, 風力発電の開発可能 地域において IRRが $8 \%$ を回る地域のみを抽出した結果 をFig. 5 に示す。開発可能地域が岩手県に遍在的に存在す る一方で，事業性がある地域はわずかに絞られ，その総面 積は $232 \mathrm{~km}^{2}$ であった。また，事業性がある地域に風力発 電を導入した際の総発電量は 3.0 TWh であり, これは岩手 県の電力需要の $35 \%$ に相当した ${ }^{23)}$ 。

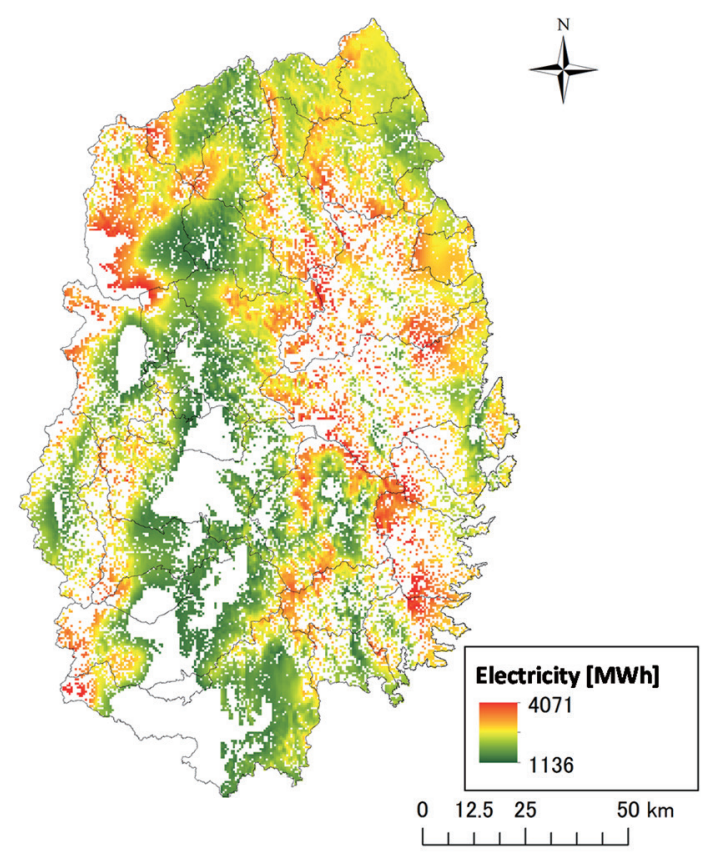

Fig. 4 Distribution map for annual electricity generation

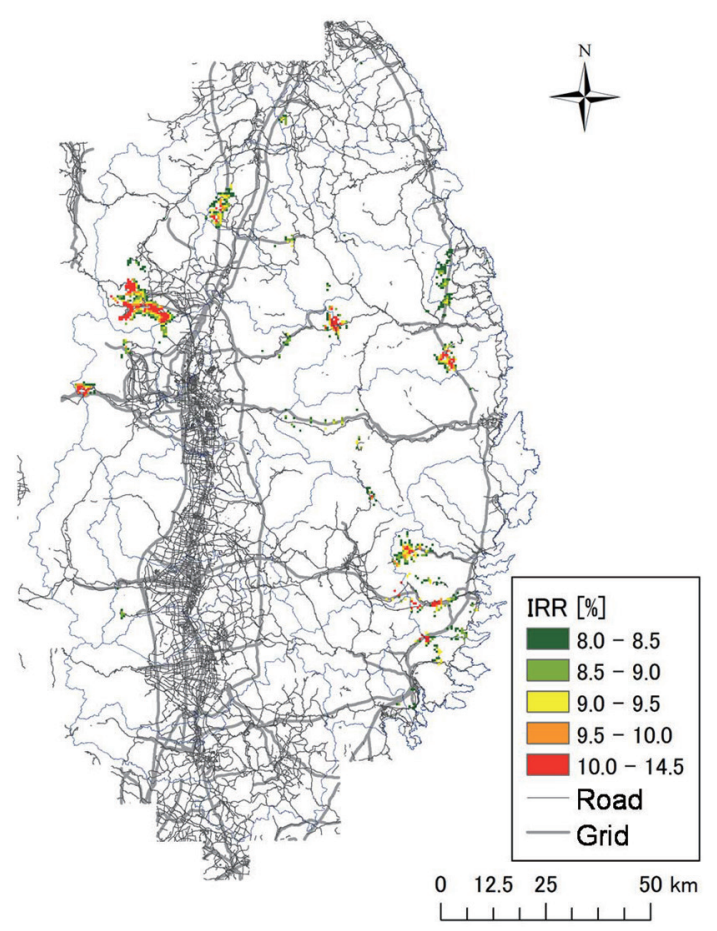

Fig. 5 Distribution map above $8 \%$ of IRR

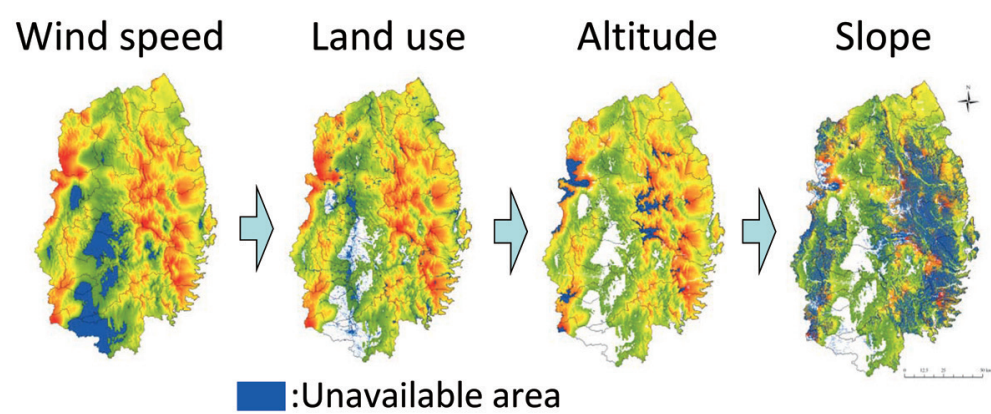

Fig. 3 Steps of estimation of available area 


\section{3 事業性の感度分析}

固定価格買取制度が開始して以降, 風力発電に必要な IRR は $8 \%$ とされてきた。しかしながらこれは，利潤配慮お よび供給量の状況を勘案して決定された值であり，今後検証 が必要な数值だされている24)。そこで本論文では，事業 性の基準值を IRR が 4\% 以上，6\%以上と設定した条件を加 え導入ポテンシャルを算出し，8\%での結果を含め比較した。 各基準における面積や総正味年間発電量などを Table 5 に示す。

事業性があると判定された地域の総面積は岩手県の面積 に対して，IRR 4\%以上のとき約 $16.3 \%$ ，IRR 8\%以上のとき 約 1.5\%に相当した。IRR $8 \%$ 以上と設定した場合と比較して, IRR 4\%以上の総正味年間発電量および総面積は 9.2 倍およ び 10.8 倍と大きく増加した。また，事業性の基準を厳しくす ると，平均設備利用率は大きくなり，平均初期投資費用は小 さくなった。IRRの基準值が $2 \%$ 大きくなるごとに，約 2 円 $/ \mathrm{kWh}$ 安くなることが分かった。

資源エネルギー庁の試算では, 陸上風力発電の発電コス

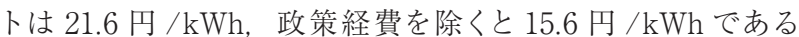
25)。事業性を考慮せず開発可能地域の全域に風車を導入し た場合では，年間で 73.4 TWh の発電量を見込むことが可 能である一方で平均発電コス卜は 24.7 円 / kWh と大幅に高 い值となるが, 本論文で算出した発電コストで最も近い值は, IRR が $8 \%$ 以上の場合で, 総発電量は 3.0 TWh に対し平均 発電コストが 15.4 円 / kWh であった。資源エネルギー庁の 試算方法では, 設備利用率を $20 \%$ と設定し発電量を推計し ているが，本論文では，IRRが $8 \%$ 以上のときの平均設備利 用率は 40.5\%であった。資源エネルギー庁の系統接続費用 は, 風力発電の建設費の $5.2 \%$ と設定している。しかし，本 論文では地域ごとにこの費用を算出しており，本論文の初期 費用は資源エネルギー庁のそれよりも大きな值を取ることが 多い。つまり，資源エネルギー庁の試算と比較すると，本論 文は風力発電の発電量だけでなく，初期投資費用も大きく 評価しているといえる。

\section{4 事業性を考慮した導入ポテンシャル}

算出した IRR が $8 \%$ 以上となった地点は，概して発電量 の高い地域に集中している結果となった。その一方で，発電 量が高い地域の中にも IRRが低い地点が存在した。そこで, IRRが低い地点の要因を自然条件および社会条件の観点か ら考察するため, IRR が等しく $5.0 \%$ となった地点の中から

Table 5 Estimated results depends on IRR

\begin{tabular}{l|c|c|c}
\hline & \multicolumn{3}{|c}{ IRR } \\
\cline { 2 - 4 } & $4 \%$ & $6 \%$ & $8 \%$ \\
\hline Total area $\left[\mathrm{km}^{2}\right]$ & 2,495 & 890 & 232 \\
\hline Toal annual electricity [TWh] & 27.3 & 10.6 & 3.0 \\
\hline Average utilization factor [\%] & 34.7 & 37.7 & 40.5 \\
\hline Average initial cost [Million Yen] & 640 & 618 & 587 \\
\hline Average electricity cost [Yen/kWh] & 19.5 & 17.3 & 15.4 \\
\hline
\end{tabular}

道路および送電系統に対する立地が異なる 3 地点を選択し， IRR が $9.0 \%$ と高い結果を示した代表地点と比較した。これ ら地点選択の主要点をTable 6 に, 選択した地点の位置を Fig. 6 に示す。IRR 9.0\%の代表地点を A とし, IRR が 5.0\% と低い代表地点を B-D としている。各代表のこれら各地点 に扮ける年間発電量と初期投資費用の内訳を算出し比較し た結果を Fig. 7 に示す。

各地点において，必要な設備費用と開業費用に差はない。 そのため, IRRに差ができる要因は, 年間発電量または道 路整備費用, 送電線敷設費用のいずれかである。地点 $\mathrm{A}$ で は正味年間発電量が高く，必要な初期投資費用も小さいこ とから，IRRが $9.0 \%$ と高い值となった。一方で，地点 B お

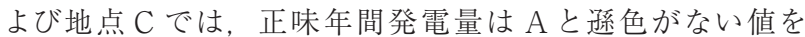
示した一方で, IRRが $5.0 \%$ とささい值となった。B 地点で は道路から距離があり，道路の整備に多くの費用が必要な 面が，地点 Cでは送電線から距離があり，送電線の敷設に 多くの費用が必要な面が要因でIRRが小さくなった。また地 点 D では, 必要な初期投資費用は $\mathrm{A}$ 地点と同じく小さい一 方で，風が弱く正味年間発電量が小さい結果，IRRが小さ い值をとった。IRR は発電量に大きく影響され, また, 各地 点により道路整備費用及び送電線敷設費用が変化する。そ

Table 6 Major points for each selected site

\begin{tabular}{c|c|c|c|c}
\hline \multirow{2}{*}{ Site } & \multirow{2}{*}{ IRR } & $\begin{array}{c}\text { Electricity } \\
\text { generation }\end{array}$ & to Road & to Grid \\
\hline A & $9 \%$ & High & Not far & Not far \\
\hline B & \multirow{2}{*}{$5 \%$} & High & Far & Not far \\
\cline { 1 - 3 } C & High & Not far & Far \\
\cline { 3 - 5 } D & & Low & Not far & Not far \\
\cline { 3 - 5 } & & & &
\end{tabular}

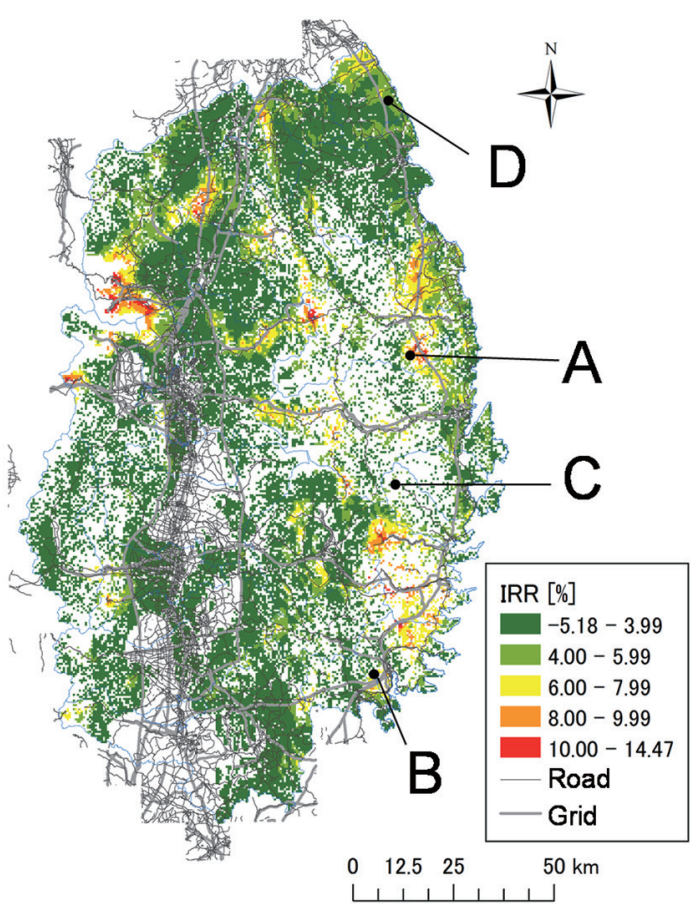

Fig. 6 Selected locations for typical examples 


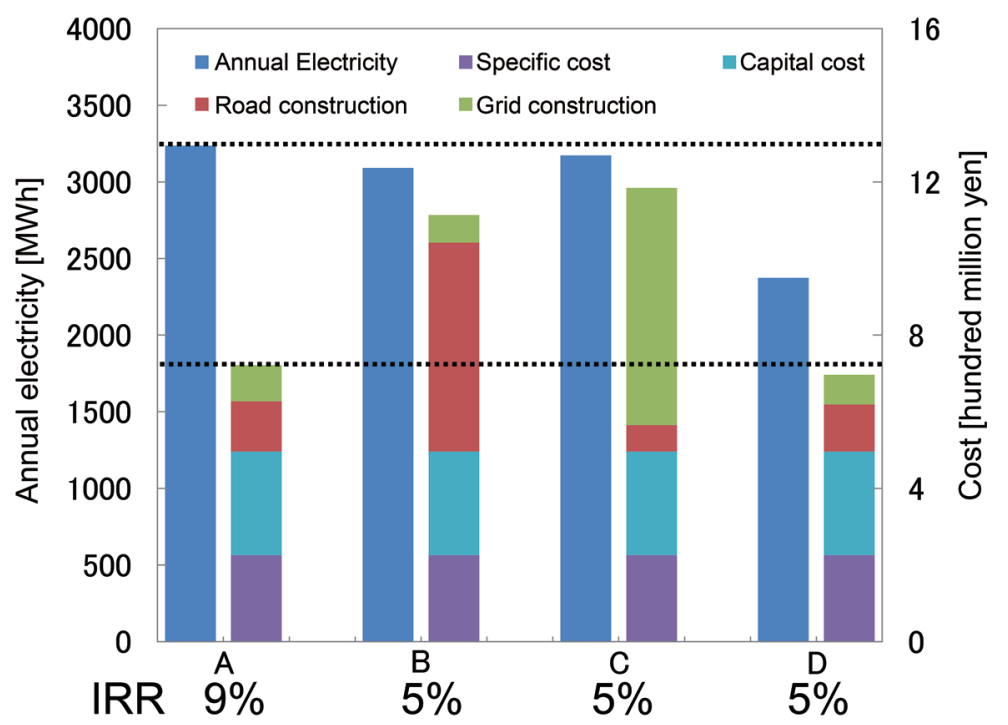

Fig. 7 Total annual electricity generation and initial costs for each selected location

のため, 風力発電が事業性を持つためには, その地域の発 電量が大きく，なおかつ道路および送電線に近い必要があ ることが定量的に明示された。

\section{4. 事業性向上のための検討}

IRR は，以上のように年間発電量と初期投資費用に左右さ れる。将来的に風力発電は, コストの低減ならびに風車の 大型化が予想される。これら二つの観点について，それぞ れ IRR 向上に寄与するかどうかを検討した。

\section{1 コスト低減時の事業性評価 (コスト低減ケース)}

世界風力会議（GWEC）によるコス卜低減シナリオである, Moderate Scenario（MS，低減率 4\%）ならびに Advanced Scenario（AS，低減率 12\%）に基づき，コストが低減され た際のIRRを算出し，事業性についての評価を行なった。 MS, AS それぞれのシナリオのコスト低減率に則り算出した 想定低減単価を Table 7 に示す。これらの值に基づき, IRR を算出した結果を Fig. 8 (a) および Fig. 8 (b) に示す。IRR が $8 \%$ 以上で事業性があると判定された地域の総年間発電 量は, MS では 3.4 TWh, AS では 4.4 TWh であり, 総面積 は MS, ASそれぞれ $266 \mathrm{~km}^{2}, 354 \mathrm{~km}^{2}$ であった。これは 岩手県の総面積の $1.7 \%$ 拈よび $2.3 \%$ に相当する。また，コ ス卜低減がない基準時の面積からの増加率は MS で $14.7 \%$, AS で $52.6 \%$ となり，大きく増加する。

\section{2 大型風車の導入時の事業性評価(大型風車導入ケース)}

定格出力 $5 \mathrm{MW}$ の大型風車を導入することを仮定した「大 型風車導入ケース」に対し, 同様にポテンシャルの評価を 行った。なお，費用については基準ケースと同様としている。 $5 \mathrm{MW}$ 機を導入した際の IRRの算出結果を Fig. 9 に示す。 IRR が $8 \%$ 以上の地域の総正味年間発電量は $27.6 \mathrm{TWh}$, 総面積は $2,541 \mathrm{~km}^{2} て ゙ ， 2 \mathrm{MW}$ 機と比較すると，面積は 11 倍へと増加した。本評価結果においてこのようにIRRが増
大した主な理由は，メッシュあたりに必要な費用が低下した 点にある。同一メッシュにおける $2 \mathrm{MW}$ 機と $5 \mathrm{MW}$ 機の風 車での発電量と必要な費用の比較を Fig. 10 に示す。 $2 \mathrm{MW}$ 機と $5 \mathrm{MW}$ 機では, 1 基当りの発電量が増加する一方で, 面積係数が小さい，すなわち，1つのメッシュに導入可能な 風車の基数が減少するため, メッシュあたりの発電量は同程 度に留まる。評価の前提条件として, 道路整備費用や送電 線敷設費用，開業費用は風車 1 基に必要な費用としているた め, メッシュあたりに換算すると費用が小さくなる。その結果, 大型風車導入ケースにおいて IRR は全体的に増加する。

本論文では，特に，建設費用が含まれている開業費用に ついては，1基あたりに必要な費用を $2 \mathrm{MW}$ 機と $5 \mathrm{MW}$ 機 で同等として評価を行っており, 建設用超大型クレーンの機 種の違いによるコスト差などは考慮していない。また, $5 \mathrm{MW}$ 大型風車の導入には, 道路拡幅が必要になる箇所の増加, 橋梁の重量制限, トンネルの通過制限などが生じる可能性 が十分高い。このため, 輸送・建設費の増加も考慮すると, 山間部への $5 \mathrm{MW}$ 大型風車の導入可能地点は, 限定される と考えられる。

$5 \mathrm{MW}$ 機において有利なのは, 上空の風を利用できること に起因する発電電力量増加と, 同一の設備容量を持つウイ ンドファームでの場合は, 設置基数の低減によるメンテナン 又費の低減である。より精緻な試算を進めるには, これらの 前提条件を詳細に評価していく必要があり, 今後の課題とい える。

Table 7 Cost Scenarios

\begin{tabular}{c|c|c|c}
\hline Scenarios & Cost reduction & $\begin{array}{c}\text { Specific Cost } \\
{[1000 \text { Yen } / \mathrm{kW}]}\end{array}$ & $\begin{array}{c}\text { O\&M cost } \\
{[1000 \mathrm{Yen} / \mathrm{kW}]}\end{array}$ \\
\hline Moderate (MS) & $4 \%$ & 240 & 5.76 \\
\hline Advanced (AS) & $12 \%$ & 220 & 5.28 \\
\hline
\end{tabular}



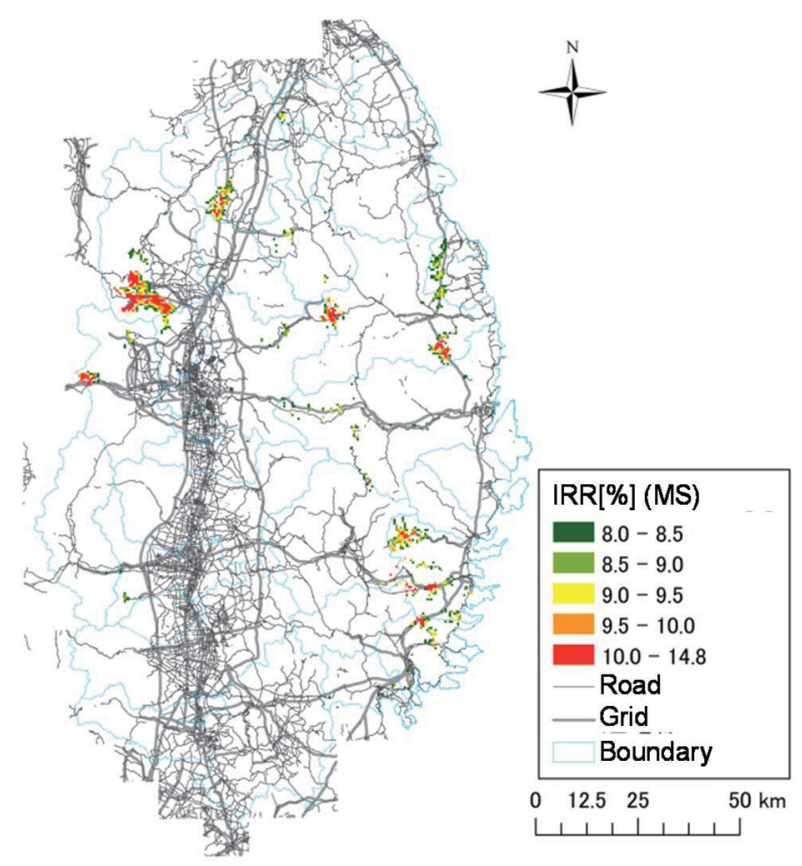

(a) Moderate scenario (MS)

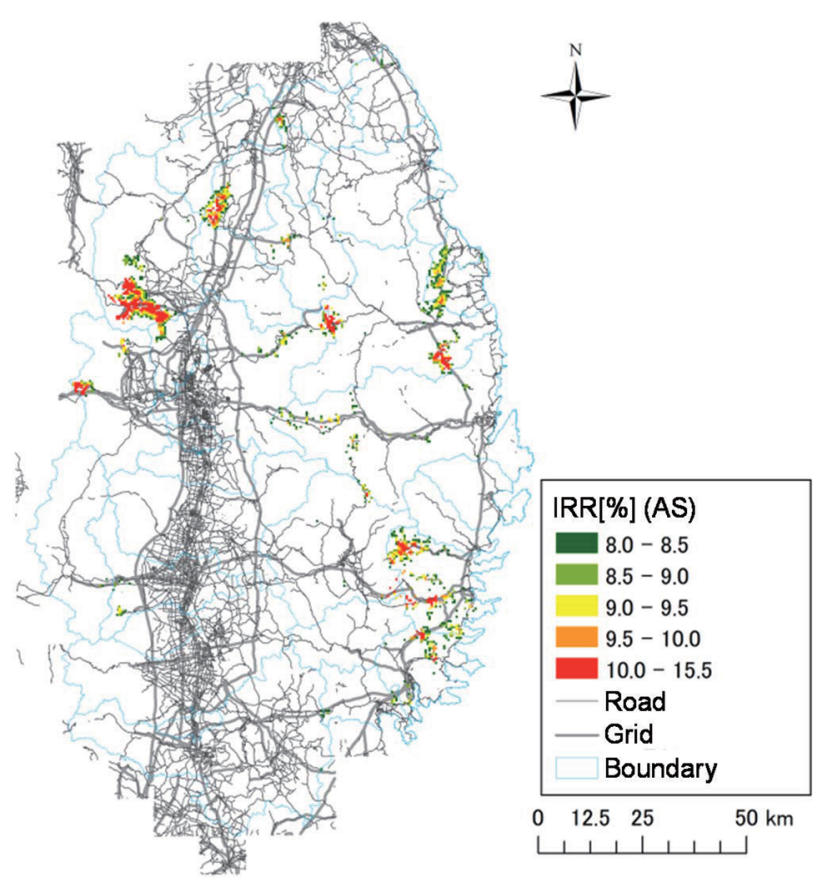

(b) Advanced scenario (AS)

Fig. 8 IRR considered cost scenarios: (a) Moderate scenario (MS), (b) Advanced scenario (AS)

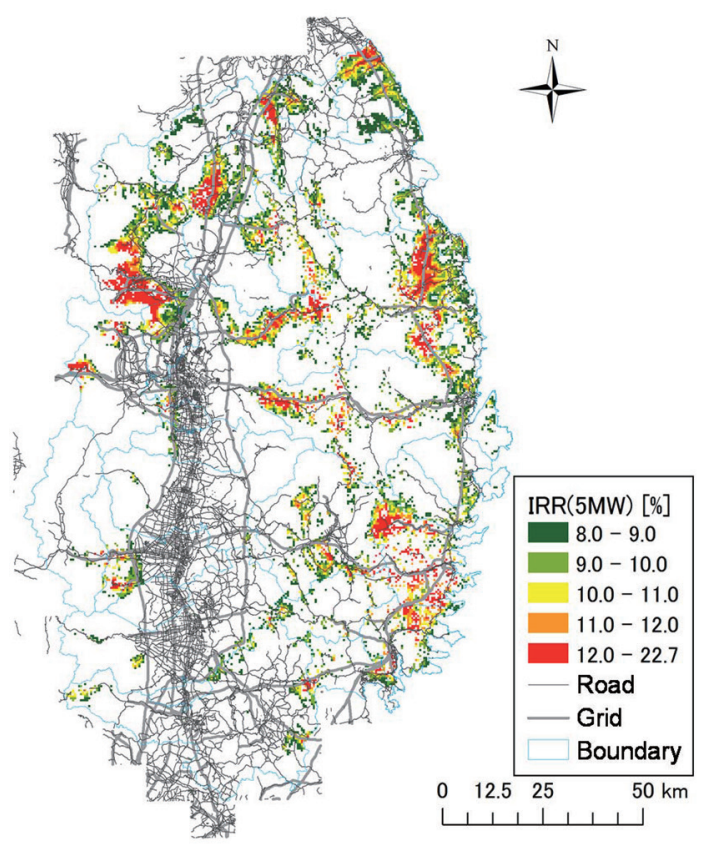

Fig. 9 IRR for $5 \mathrm{MW}$ wind turbines

\section{5. おわりに}

本論文では，東日本大震災によって被災した中でも，風 力発電のポテンシャルが高いとされる岩手県を対象に, 立 地制約を考慮した風力発電の導入量および事業性の評価を 行った。また，将来的にコストが低減した場合の事業性， 大型風車の導入ケースについても評価を行った。立地制約 を考慮すると, 岩手県の面積の約 $53 \%$ において風力発電の

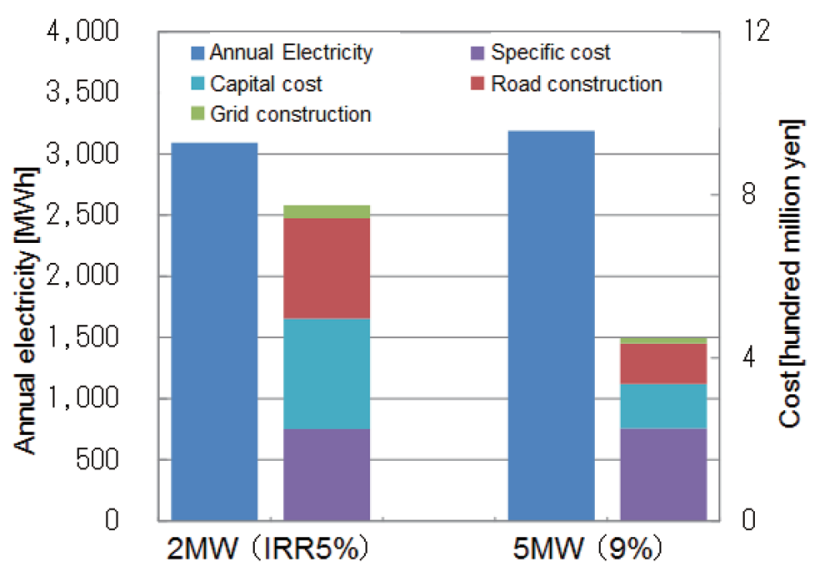

Fig. 10 Annual electricity and levelised cost of $2 \mathrm{MW}$ and $5 \mathrm{MW}$ wind turbines per data mesh size of $500 \mathrm{~m}$

開発が可能だと判定された。その開発可能地域の全域に風 車を導入した際の, 正味年間発電量は $73.4 \mathrm{TWh}$, 平均発 電コストは 24.7 円 $/ \mathrm{kWh}$ と推算された。事業性の基準值を IRR $8 \%$ 以上と設定すると, これを満たす地域は, 岩手県の $1.5 \%$ のに限られ，総発電量は年間 3.0 TWh であった。こ のときの平均発電コストは 15.4 円 / kWh と, 資源エネルギー 庁の試算と近い值を取る。

2030 年までのコスト低減率を $4 \%$ および $12 \%$ とすると, IRR が 8\%以上の地域の総面積は $266 \mathrm{~km}^{2}$ および $354 \mathrm{~km}^{2}$ であり, 今後導入が進むと予想される $5 \mathrm{MW}$ 大型風車導入 を想定したケースにおいては, IRRが全体的に増加し, IRR が $8 \%$ 以上の地域の総面積は $2,541 \mathrm{~km}^{2}$ へと増大した。コス 
卜低減ケースでの IRR 向上は微増に留まるが，大型風車の 導入により IRR は大きく向上する。これは大型風車導入によ り，単位面積あたりの道路整備費用及び送電線敷設費用等 が低減されることに起因する。

岩手県は, 発電量が大きい一方で, 道路や送電線からの 距離が遠いため，これらの費用が高く，IRRが小さい值とな る地域が多い。そのため岩手県では, 大型風車の導入によ るこれら費用の圧縮，本論文では省略した，風速の高度補 正㧍よび最新の長大ブレード風車の適用による発電量増加 により，事業性が大きく向上する可能性が高い。

\section{謝 辞}

本研究は JSPS 科研費（課題番号：24360403）の支援によ り実施されました。

\section{文 献: References}

1) Ministry of the Environment Government of Japan, Annual Report on the Environment, the Sound Material-Cycle Society and Biodiversity in Japan 2016, p. 66 (2016), http://www.env.go.jp/policy/hakusyo/h28/ pdf/full.pdf (Last access: 2016.10.14)：環境省，平成 28 年版 環境·循環型社会·生物多様性白書, p. 66 (2016), http://www.env.go.jp/policy/hakusyo/h28/pdf/full.pdf (Last access: 2016.10.14)

2) Akther, A.; Ahamed, T.; Takigawa, T.; Noguchi, R., J. Jpn. Inst. Energy, 95, 457-467 (2016)

3) Wakeyama, T.; Ehara, S., J. Jpn. Inst. Energy, 91, 391-404 (2012):分山達也，江原幸雄，日工ネ誌, 91, 391-404 (2012)

4) Fukuda, Y.; Fujii, M., J. Jpn. Inst. Energy, 94, 1057-1065 (2015)

5) Siyal, S.; Mörtberg, U.; Mentis, D.; Welsch, M.; Babelon, I.; Howells, M., Energy, 83, 447-461 (2015)

6) Sliz-Szkliniarz, B.; Vogt, J., Renewable and Sustainable Energy Reviews, 15, 1696-1707 (2011)

7) Grassi, S.; Chokani, N.; Abhari, R., Energy Policy, 45, 73$85(2012)$

8) Iwate Prefecture, Action plan for global warming, 2016, http://www.pref.iwate.jp/dbps_data/_material_/ files/000/000/002/954/jikkoukeikaku_kaitei.pdf (Last access: 2016.10.14) : 岩手県, 地球温暖化対策実行計画, 2016, http://www.pref.iwate.jp/dbps_data/_material_/ files/000/000/002/954/jikkoukeikaku_kaitei.pdf (Last access: 2016.10.14)

9) Ministry of Land, Infrastructure, Transport and Tourism, National Land Numerical Information download service, http://nlftp.mlit.go.jp/ksj/ (Last access: 2016.10.14)：国土交通省，国土数值情報ダウン ロードサービス, http://nlftp.mlit.go.jp/ksj/ (Last access: 2016.10.14)

10) Ministry of Land, Infrastructure, Transport and
Tourism, Maps \& Geospatial Information, http://www. gsi.go.jp/kibanjoho/kibanjoho40027.html (Last access: 2016.10.14): 国土交通省, 数值地図（国土基本情報）, http://www.gsi.go.jp/kibanjoho/kibanjoho40027.html (Last access: 2016.10.14)

11) Ministry of the Environment Government of Japan, Study on Basic Zoning Information Concerning Renewable Energies, 2014, https://www.env.go.jp/earth/ report/h26-05/full.pdf (Last access: 2017.3.19) : 環境省, 平成 25 年度再生可能エネルギーに関するゾーニング基礎 情報整備報告書, 2014, https://www.env.go.jp/earth/ report/h26-05/full.pdf (Last access: 2017.3.19)

12) Ministry of the Environment Government of Japan, Study of Potential for the introduction of Renewable Energy, 2011, https://www.env.go.jp/earth/report/h2303/full.pdf (Last access: 2017.7.20)：環境省，平成 22 年度再生可能エネルギー導入ポテンシャル調査報告書, 2011, https://www.env.go.jp/earth/report/h23-03/full. pdf (Last access: 2017.7.20)

13) Ministry of the Environment Government of Japan, Study of Potential for the introduction of Renewable Energy, 2010, http://www.env.go.jp/earth/report/h2202/full.pdf (Last access: 2017.3.19) : 環境省, 平成 21 年度 再生可能エネルギー導入ポテンシャル調査報告書, 2010, http://www.env.go.jp/earth/report/h22-02/full.pdf (Last access: 2017.3.19)

14) Ministry of the Environment Government of Japan, Study on Basic Zoning Information Concerning Renewable Energies, 2016, https://www.env.go.jp/earth/ report/h28-03/h27_whole.pdf (Last access: 2017.3.19) : 環境省, 平成 27 年度再生可能エネルギーに関するゾー ニング基礎情報整備報告書, 2016, https://www.env. go.jp/earth/report/h28-03/h27_whole.pdf (Last access: 2017.3.19)

15) New Energy and Industrial Technology Development Organization (NEDO), The guidebook for wind energy, 2008, http://www.nedo.go.jp/content/100079735.pdf (Last access: 2016.10.14) : 新エネルギー産業技術総合開発 機構（NEDO), 風力エネルギー導入ガイドブック, 2008, http://www.nedo.go.jp/content/100079735.pdf (Last access: 2016.10.14)

16) Iwate Prefecture, Report for wind energy action plan, 2015, http://www.pref.iwate.jp/dbps_data/_material_/ files/000/000/002/954/jikkoukeikaku_kaitei.pdf (Last access: 2016.10.14) : 岩手県, 風力発電導入構想策定報 告 書, (2015), https://www.pref.iwate.jp/dbps_data/_ material_/_files/000/000/037/272/houkokusyo.pdf (Last access: 2016.10.14)

17) Hitachi, Ltd, HTW2.0-80 specification, http://www. hitachi.co.jp/products/power/wind-turbine/products/ 
htw2000_80/specification/index.html (Last access: 2017.3.19)：日立製作所 HP, HTW2.0-80 諸元, http:// www.hitachi.co.jp/products/power/wind-turbine/ products/htw2000_80/specification/index.html (Last access: 2017.3.19)

18) Hitachi, Ltd, HTW2.0-80 performance, http://www. hitachi.co.jp/products/power/wind-turbine/products/ htw2000_80/performance/index.html (Last access: 2017.3.19)：日立製作所 HP, HTW2.0-80 性能, http:// www.hitachi.co.jp/products/power/wind-turbine/ products/htw2000_80/performance/index.html (Last access: 2017.3.19)

19) Saeki, M.; Tobinaga, I.; Sugino, J.; Shiraishi, T., Hitachihyoron, 92, 340-345 (2014) : 佐伯満, 飛永育男, 杉 野淳一, 白石崇, 日立評論, 96, 340-345 (2014)

20) New Energy and Industrial Technology Development Organization (NEDO), Wind conditions map, http:// app8. infoc.nedo.go.jp/nedo/ (Last access: 2016.10.14) : 新エネルギー産業技術総合開発機構 (NEDO), 局所風況 マップ, http://app8. infoc.nedo.go.jp/nedo/ (Last access: 2016.10.14)

21) Ministry of Economy, Trade and Industry, Procurement price calculation committee, Settlement of FY 2016 Purchase Prices and FY 2016 Surcharge Rates under the Feed-in Tariff Scheme for Renewable Energy, 2016, http://www.meti.go.jp/committee/chotatsu_kakaku/ pdf/report_005_01_00.pdf (Last access: 2017.3.19) : 経済 産業省調達価格等算定委員会, 平成 28 年度調達価格及 び調達期間に関する意見，2016，http://www.meti.go.jp/ committee/chotatsu_kakaku/pdf/report_005_01_00.pdf (Last access: 2017.3.19)

22) Global Wind Energy Council, Global Wind Energy Outlook 2014, 2014, https://www.gwec.net/wp-content/ uploads/2014/10/GWEO2014_WEB.pdf (Last access: 2016.10.14)

23) Agency for Natural Resources and Energy, Statistics of energy consumption by prefectures, 2014, http://www. enecho.meti.go.jp/statistics/energy_consumption/ec002/ results.html. (Last access: 2017.3.19) : 資源エネルギー庁, 都道府県別エネルギー消費統計調查，2014，http://www. enecho.meti.go.jp/statistics/energy_consumption/ec002/ results.html. (Last access: 2017.3.19)

24) Ministry of Economy, Trade and Industry, Procurement price calculation committee, Settlement of Purchase Prices for Renewable Energy, 2-3 (2015), http:// www.meti.go.jp/committee/chotatsu_kakaku/pdf/ report_004_01_00.pdf (Last access: 2016.10.14) : 経済産 業省調達価格等算定委員会, 調達価格及び調達機関に関 する意見， 2-3 (2015), http://www.meti.go.jp/committee/ chotatsu_kakaku/pdf/report_004_01_00.pdf (Last access: 2016.10.14)

25) Agency for Natural Resources and Energy, http://www. enecho.meti.go.jp/committee/council/basic_policy_ subcommittee/mitoshi/cost_wg/pdf/cost_wg_01.pdf (Last access: 2016.10.14)：資源エネルギー庁, http:// www.enecho.meti.go.jp/committee/council/basic policy_subcommittee/mitoshi/cost_wg/pdf/cost_wg_01. pdf (Last access: 2016.10.14) 